\title{
The Challenges and Solutions of Teachers' Problems to Achieve Education Golden Era
}

\author{
Zalik Nuryana $^{1,2, *}$, Indah Nurcahyati ${ }^{3}$, Arif Rahman ${ }^{1}$, Farid Setiawan $^{1}$, Dani Fadillah $^{4}$ \\ ${ }^{1}$ Department of Islamic Education, Universitas Ahmad Dahlan Yogyakarta, Indonesia \\ ${ }^{2}$ School of Educational Science, Nanjing Normal University, China \\ ${ }^{3}$ SMA Negeri 1 Cangkringan Yogyakarta, Indonesia \\ ${ }^{4}$ Department of Communication, Universitas Ahmad Dahlan Yogyakarta, Indonesia
}

Received December 9, 2019; Revised December 28, 2019; Accepted January 16, 2020

Copyright $\bigcirc 2020$ by authors, all rights reserved. Authors agree that this article remains permanently open access under the terms of the Creative Commons Attribution License 4.0 International License

\begin{abstract}
This research aims to describe the problems of education in terms of the budget, accreditation, and teachers as well as the challenges of developing them, and solutions to the problems of education in Indonesia. This research is a literature review. Data collected through the Central Statistics Agency and Education data from the Indonesian Ministry of Education. The data is then explained and analyzed critically to provide conclusions in the context of designing and solving education problems in Indonesia to welcome the golden era. Education should soon adapt to era development if it is not willing to be left. A country's responsibilities in overseeing the education to achieve a golden education era are required. The planning, process and results of education will reflect the quality of the nation. The results showed that the problem of absorption of school budgets, equitable distribution of school accreditations, and teacher problems were important things that needed to be resolved immediately. This study provides a contribution to the new strategic plan on how to achieve the golden era of education, there not much research focuses discuss the budget, accreditation, vocational education, and character education as the basis for the determination of educational policy. The conclusion is the government should focus more on equity of Education budget absorption, enhancement of teachers from the aspect of skill and well-being, to make vocational education as an arrow civilization, and making character education as a human resource control to keep moral and intellectual integrity.
\end{abstract}

Keywords Education Issues, Education Challenge, Education Solution, Education Golden Era, Education Success Strategy

\section{Introduction}

Highlight Education becomes an important pillar for a nation. Planning, process and result of education will reflect the nation quality. Great education implementation in a country will affect many things, such as economic growth [1] and [2] nation's civilization, future, societies and cultures, and human resource to develop the country. For example in Malaysia, in 1974, this country focused on building skill and religious integration-oriented education[1]. In China, the movement of new reformation of education direction has long occurred, however, in 1980, the focus of the education was oriented on teachers' development and reformation [2], and the development ability improvement was carried out continually [3]. In South Africa, education reformation is also performed [4], It is what also occurs in New Zealand [5].

In Indonesia, school-based management becomes the pioneer to improve the education quality [6]. Education decentralization in Indonesia remains some issues such as; the lack of transparence and accountability in administrational implementation, the increase of significant financing, and high social and gap [7]. A new policy on Local Content Curriculum which centers on local-based education management has emerged. It causes a new issue on the unpreparedness of local resource to implement the program [8]. In 2013, Cultural and Education Ministry issued a new policy which is called as Curriculum 2013 or is known as K13. The implementation still indicated many unprepared schools and resources which was proven with many implementations that have not followed the determined regulations [9]. 


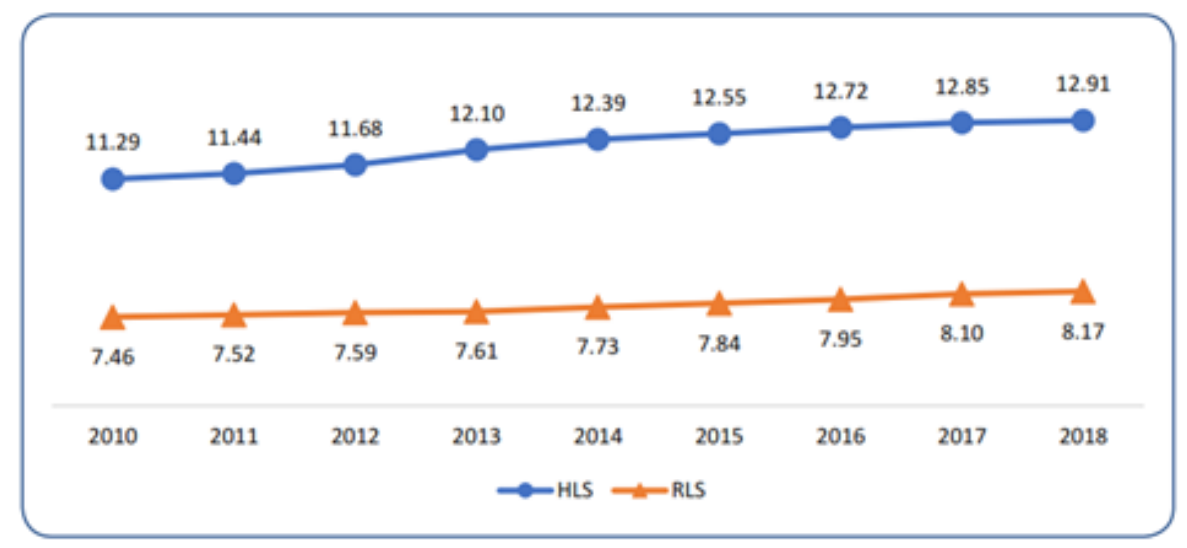

Figure 1. Length Expectation of School and Length Average of School in Indonesia, 2010-2018

The data of Statistical Center Bureau announced [10] that 2018 was the third year when Indonesia had "high" human development status with Life Expectancy of birth reaching 71.20 years. It means that new born baby can survive until 71.20 years old. In average, the populations of Indonesia whose age is 25 years old and above have undergone 8.17 years of school period or have completed the education which is equal to Grade VIII. Besides, the average of 7 year-old populations who have started to study are expected to continue the education to 12.91 years or is equal to Diploma I. It is not less important that decent standard of living in Indonesia is represented by the indicators of per capita expenditure which are adjusted have reached IDR 11.059.000, 00 per capita/year. This achievement is pleasing for us. It because the spirit that Indonesia golden era will be soon manifested.

The dimension of knowledge on Human Development Index is shaped by two indicators, which is Length Expectation and Average Length of School of 25 year-old populations and older. Figure 1 explains that the indicator is increasing over year. For the period 2010 to 2018, the Length Expectation of School in Indonesia has increased to 1.62 years, while the Average Length of School is increased to 0.71 years.

Based on Statistical Central Bureau, it is explained that from 2010-2018, the average length of school is increased to $1.70 \%$ annually. It indicates the more societies study. While the school length of societies in their 25 years old and older grew 1.14 percent annually from 2010 to 2018. It becomes an important capital for quality development through education sector. This development becomes the spirit for the government to maximize the role of education in Indonesia. If education system is more maximized, possibly the Human Development Index of Indonesia will jump far and leave the neighborhood countries.

This practice requires cooperation of all parties. A good education implementation need more mature collaborations and integration. Many problems at school such as problems of teachers [11], Management [12], Funding [13] [14], school, curriculum, facility and infrastructure, learning process [15] etc. All of them rise problems and critics. However, it does not reduce the spirit to innovate, grow and develop the education in Indonesia. This article tries to explain the problems and challenges of education development in Indonesia to welcome the golden era.

\section{Materials and Methods}

This research is a literature analysis with literature review. The data was collected through Statistical Center Bureau and Education data of Ministry of Education and Culture of Indonesia. Furthermore, the data was critically explained and analyzed to draw the conclusion in order to design and solve education problems in Indonesia and welcome the golden era. The data obtained is presented in the form of tables, pictures, and narratives. After the data is presented, the researcher makes a descriptive qualitative analysis. Educational data is based on the ministry of education, because the data is valid based on a survey conducted. Then the data is collected and then sorted and selected according to the needs in this study. For example data on school operational costs, school accreditation gaps, and teacher problems.

Primary data consisted of reading and note-taking techniques, while secondary data consisted of library research techniques. The things that are used in the method include reading techniques, used to read references and related research. The note-taking technique is used to record parts of the data source in accordance with problems related to this research. And library research techniques are used to search for and find data from various references to support the subject and focus of research. The instrument used in this study was the research itself, namely the researcher as the perpetrators of the entire study. The research itself plays a role in planning and reporting the results of its research. Data collection is done using computer aids. Computers are used as a medium to record important information to be analyzed that comes from Indonesian Ministry of Education or outside that is related to the problem to be 
studied.

In this study, the validity of the data is obtained through validity and reliability. The steps taken to measure validity in this study use construct validity, semantic validity, and referential validity. Construct validity is to assess how much a functional analysis procedure model refers to the relationship to the data context. This form of validity is principally related to the acceptance or rejection of the basic analytical structure in the structural, functional processes and categories of analysis that are demonstrated by model theory and knowledge of the data context.

Data reliability in this study was carried out with intrarater reliability. That is, researchers read and examine research subjects repeatedly and continuously until they get consistent data and their inferences. In addition, it also uses intrerater reliability, the reader to understand the data and theoretical framework to discuss with other author they have the ability to understand the data and theoretical framework used.

The data analysis technique that will be used in this research is descriptive qualitative. The data analysis technique is a comparison of the data, by comparing the data verbally. Categorization is grouping data according to the focus of research, namely solutions to achieve the golden era of education. Presentation of data in the form of tables and figures, and finally the making of inference, which means understanding and concluding the data found in tracing data in the Indonesian Ministry of Education

Based on many problems which are explained in this article, we purse it into three (3) education development focusses which strongly affect education, such as problems of education financing, School Accreditation, and Teachers. The government is supposed to more focus on developing these three things although other education facilities and infrastructures are not less important. The Cultural and Education Ministry data in 2018 explained that in 2018, there were $8.2 \%$ Elementary Schools, 15\% Junior High Schools, $14.6 \%$ Senior High School and 37\% Vocational High School which have not been accredited. Based on this data, we could see that Vocational High School is positioned on the highest percentage concerning the numbers of schools which have not been accredited. Whereas, campaign to promote Vocational High School is incessantly carried out. The government should be more serious to perform development so that the numbers of school which have not been accredited will decrease. There are many education problems [16], in this research, the problem is explained not to show a weakness of education system but build a base to determine future policy. Indonesia has a very big opportunity in the promotion of Vocation education. However, the problem of elementary to college education should also be considered. The government should not only prioritize on one education, but all.
This study illustrates the problem of absorption of the education budget, accreditation, and teacher problems. of course this is a local issue but the world at large can see how local governments act creatively to be able to develop education in their regions.

\section{Education Budget as School Operational Footing}

The data of education budget allocation is obtained from cultural and education ministry website [17]. The 20\% allocation of government fund which is obtained from Local Government Budget is categorized as low for education. It is based on our collective analysis that human resource investment in the education field are not perceived in 1-5 years. It will be perceived in future 19 years in our young generation. The absorption and use of budget allocation in 2018 which can be seen in the figure 2. are increasing by the year. This example took the sample of Special Region of Yogyakarta Province which is known as an education city in Indonesia. It indicates that the education budget is more absorbed to develop the education.

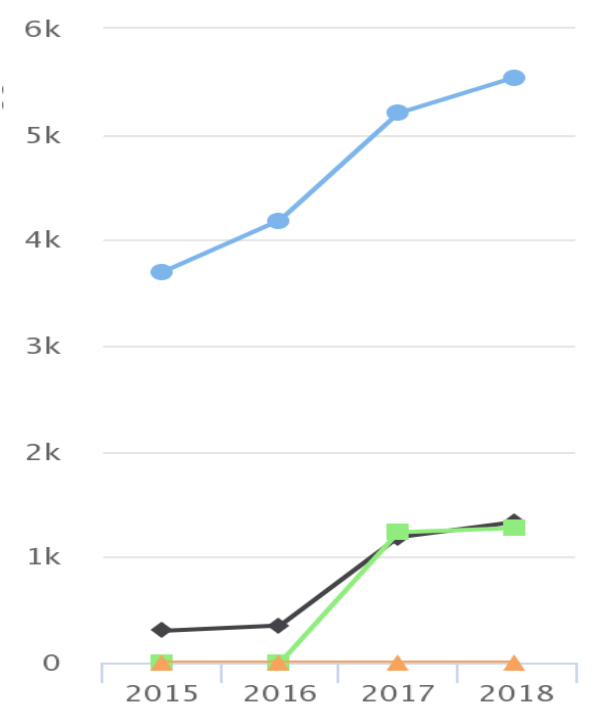

Figure 2. The Trend of Education Budget Allocation from 2015-2018 Special Region of Yogyakarta Province

This increase enables the school to maximize the existing fund. Education allocation raises some problems. However, as seen on the local education balance website, the culture and education ministry presents it as national and international discourse. Table 1 explains that the government grants appreciation to local governments who implement the program innovation. Among the programs, it is stated to omit and analyze problems on education budget. The role of local government becomes very central in using the budgeting and designing supporting programs. The culture and education ministry has innovation to designate local government who has solution innovation concerning education budgeting problems 
Table 1. Creative programs which are carried out by the local government to solve problems concerning education budget

\begin{tabular}{|c|c|c|l|}
\hline No. & Indicators & \multicolumn{1}{|c|}{ Category } & \multicolumn{1}{c|}{ Program } \\
\hline 1 & $\begin{array}{c}\text { Education } \\
\text { Budget }\end{array}$ & $\begin{array}{c}\text { Budgeting } \\
\text { Commitment of } \\
\text { Local Government }\end{array}$ & $\begin{array}{l}\text { Pangandaran Regency } \\
\text { Pangandaran Regency Government provides Special Financial Assistance to Government } \\
\text { of West Java Province to distribute it to state Senior High Schools and Vocational High } \\
\text { Schools in form of grant activity which amount is IDR 9.6 billion to 4 Senior High Schools } \\
\text { and 4 Vocational High Schools. }\end{array}$ \\
\hline & & $\begin{array}{l}\text { West. Kutai Regency } \\
\text { The annual budget addition given to education agency to increase education affairs budget. }\end{array}$ \\
\hline & & $\begin{array}{l}\text { Ternate City } \\
\text { The Education Care Organization: make the NPD data as the comparison between a } \\
\text { regency and city to another in order to boost the Local Government so that they are more } \\
\text { concerned towards education. }\end{array}$ \\
\hline & $\begin{array}{l}\text { Central Bangka Regency } \\
\text { Education agency has presented a suggestion on CSd R assistance to PT. Angkasa Pura 2 } \\
\text { and PT Kobatin. Schools deliver the CSR assistance suggestion to the company and it is } \\
\text { acknowledged by Education Agency. }\end{array}$ \\
\hline
\end{tabular}

\section{School Accreditation and Country State Pillar}

Based on the accreditation data obtained from culture and education ministry website [18], school accreditation becomes one of instruments to assess the school. It is because the education national standard in Indonesia refers to the eight national standards which are implemented in the accreditation. Figure 3 provides the comparison image of 2 provinces, which are Jakarta as the Indonesia Capital City and Yogyakarta as the Education City. The comparison indicates many schools in Indonesia which have not been accredited

100

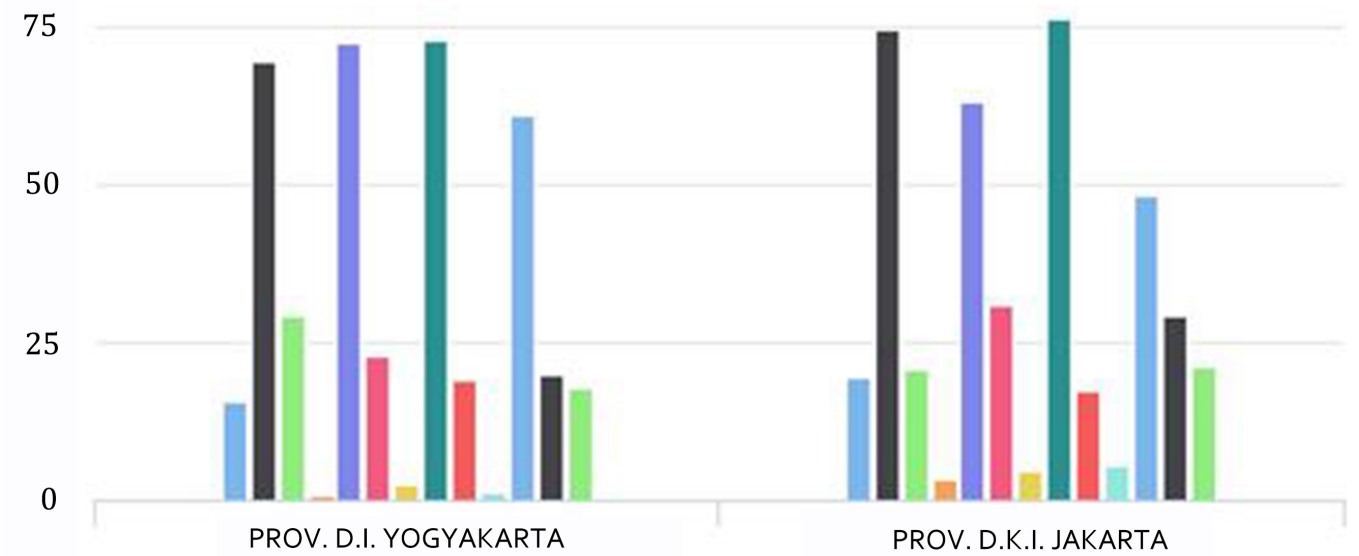

Figure 3. The comparison of Elementary School, Junior High School, Senior High School and Vocational High School accreditation in Yogyakarta and Jakarta

The yellow figure indicates the level of Elementary Schools which have not been accredited. 0.87\% elementary schools in Yogyakarta and 3.56\% in Jakarta have not been accredited. Meanwhile, the green color indicates Vocational High Schools which have not been accredited. The numbers is sufficiently high, which is $17.69 \%$ Vocational High Schools in Yogyakarta and $21.26 \%$ Vocational High School in Jakarta have not been accredited. It is similar with education budgeting problem, accreditation problem creates local government innovation to build a power for accreditation equality as explained in Table 2. This activity should be presented massively so that each local government possesses their own innovation and color the education development in Indonesia. 
Table 2. Local Government Commitment to Increase the Numbers of Accredited Schools

\begin{tabular}{|c|c|c|l|}
\hline No. & Indicator & \multicolumn{1}{|c|}{ Category } & \multicolumn{1}{c|}{ Program } \\
\hline 2 & $\begin{array}{c}\text { School } \\
\text { Accreditation }\end{array}$ & $\begin{array}{c}\text { The Local government } \\
\text { commitment to increase the } \\
\text { numbers of accredited schools }\end{array}$ & $\begin{array}{l}\text { Mentawai Archipelago Region } \\
\text { Performing activity to prepare the school in order for the accreditation on } \\
\text { Elementary School and Junior High School Level. }\end{array}$ \\
\hline & & $\begin{array}{l}\text { Balangan Regency } \\
\text { Performing periodic monitoring of school accreditation data and ensuring } \\
\text { that the schools recognize the accreditation time of education unit one (1) } \\
\text { year prior to the accreditation implementation. }\end{array}$ \\
\hline & & $\begin{array}{l}\text { Mahakam Ulu Regency } \\
\text { The renovation and development of infrastructure and facilities is } \\
\text { performed as the increase of teachers' qualification as one of accreditation } \\
\text { assessments. }\end{array}$ \\
\hline & & $\begin{array}{l}\text { Tanjungpinang City } \\
\text { The existence of some schools which involve students' parents to develop } \\
\text { their infrastructure and facility increases the number of Junior High } \\
\text { School accreditation. } \\
\text { Optimal supervision which is performed by Supervisor. }\end{array}$ \\
\hline
\end{tabular}

According to the previous program, we can evaluate whether or not many schools are accredited in 2-5 years in the future. Besides local government, the central government should perform stimulus so that the education distribution in Indonesia can run well with an indication that all schools obtain accreditation. It means that the minimum standard of accreditation assessed standard good score.

\section{Teachers Are the Main Elements in the Education Implementation}

Teachers' data is obtained from culture and education ministry [19]. Certainly, teachers become the factor that determines the process of education. Figure 4 is the comparison of teachers' qualification as the prevailed regulations. The importance of teachers' role becomes the focus so that the education quality in Indonesia can be developed.

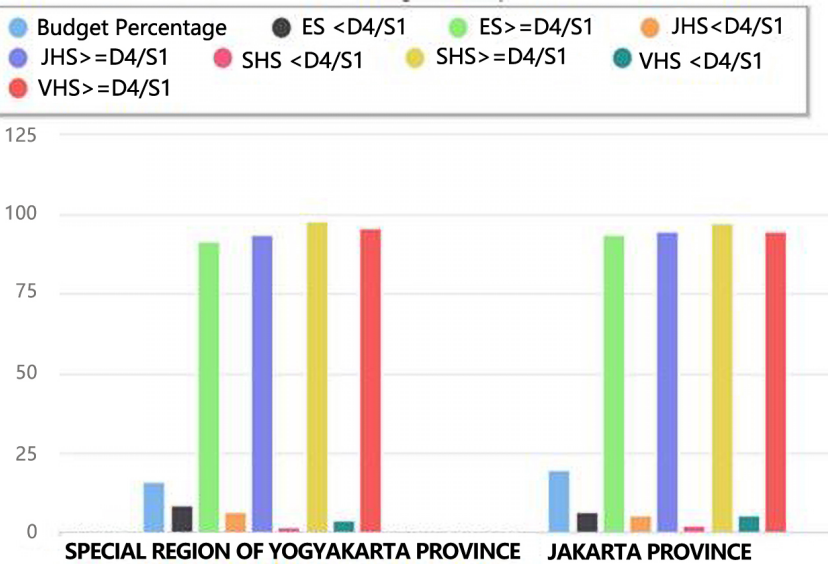

Figure 4. The comparison of teachers' qualification in Yogyakarta and Jakarta Province

The previous data indicates that many teachers of Elementary School have not fulfilled the qualification of $>$ D4 /S1. It is found that $8.23 \%$ elementary school teachers in Yogyakarta which is called as student city and $6.5 \%$ in Jakarta have not fulfilled the qualification. It is certainly a collective work. In the effort of teachers' quality improvement which is seen from the achievement in teachers' minimum quality, table 3 explains the role of creative local government to build a program in order to improve the teachers' quality.

Table 3. Local government program in order to improve teachers quality which are taken from 12 regions written on Culture and Education Ministry website

\begin{tabular}{|c|c|c|c|}
\hline No. & Indicator & Category & Program \\
\hline \multirow[t]{3}{*}{1} & \multirow[t]{2}{*}{ Teacher } & $\begin{array}{l}\text { Honorary } \\
\text { Teachers } \\
\text { Problems }\end{array}$ & $\begin{array}{l}\text { Pangandaran Regency } \\
\text { The local government provide } \\
\text { additional stipend to honorary } \\
\text { teachers, which is IDR } 3,000,000 \\
\text { annually to } 1800 \text { teachers. } \\
\text { Program of Pangandaran Recites: } \\
\text { The local government grants } \\
\text { rewards to } 7000 \text { recitation } \\
\text { teachers to support non formal } \\
\text { education. }\end{array}$ \\
\hline & & & $\begin{array}{l}\text { North Sumatera Province } \\
\text { Providing Honorary Fee } \\
\text { (Stipend) to Honorary Teachers } \\
\text { that has been managed in the } \\
\text { Local Government Budget of } \\
2019 \text { for } 8,485 \text { people experience } \\
\text { increase from IDR } 40,000 \text { to IDR } \\
90,000 / \text { lesson hour. This policy } \\
\text { program has been performed for } \\
2 \text { years. }\end{array}$ \\
\hline & & & $\begin{array}{l}\text { Langkat Regency } \\
\text { Providing IDR } 150,000 \text { as } \\
\text { monthly incentive to honorary } \\
\text { Elementary School and Junior } \\
\text { High School Teachers. }\end{array}$ \\
\hline
\end{tabular}

Table 3 is only the example of program creativity example which is performed by local government. Many other programs which have not been recorded in this article. The information source is obtained from official website of culture and education ministry. If the program is evaluated and get positive and significant result in some future years, 
the central government should provide special program assisted by expert team to each region and for managing demographic-based education quality improvement program to achieve more maximum result.

\section{The Opportunity to Reach Golden Era through Education}

The struggle to reach nation's development is not easy and cannot be done in a flash in the pan. Education golden era in Indonesia is no longer anymore. It is reflected with concept of Education National Standard Body that has organized the standard and criteria of implementation at school. So, it requires a strategy in the school implementation. Besides togetherness and communication among level, strategies should be considered. First, School Principal managerial system. Why is School Principal? Because school principal will implement the school every day. A great school principal will bring school development. Therefore school principal should be prepared. Encarnacion Garza et.all, in his research in America and Australia found that school principals who bring their school success have a secret that should be the inspiration of other school principals, among them is: Success school principal has extraordinary personal affection, strong philosophical base on social justice, bright idea, leadership ethic and strong responsibility, high survival level, and bravery [20]. Such leadership characteristic will bring school development. Besides, there are still many descriptions, jobs and characteristics of school principals that cannot be explained in this short essay, paragraph [21], dan paper.

Second is teachers. Teachers becomes an important pillar for the development of education. Teachers should realize that their profession is not only to earn the life, but also the other things. Teacher profession becomes the nation's future bet. Teacher's awareness should be strengthened. Concerning the problems, roles, functions and main jobs of teachers, it is agreed by the researchers that teacher is the most important factor in the education implementation. The anxiety of teacher's problem such as quality [22], skill [23], character [24], etc. should be brushed aside. So far, teachers have implemented their task well. The support which are given by all parties are required.

Third is curriculum. The position of curriculum is crucial for the education process. At present, the definition is far wider and convers all learning experiences which are planned by the school or educational institutions. The three curriculum levels should be in form of communicable form towards them who are related to educational institution, should be opened towards critics and can be easily altered into practices [25]. The importance of curriculum becomes the focus of many education researchers [26] [27], in Indonesia, curriculum 2013 becomes a powerful weapon which is planned by the government to reach education golden era in this country although the implementation in field still raises problems [28] [29]. However, the government should control the implementation and perform an improvement to follow the era development.

\section{Vocation Education as Development Guard}

Vocation education is higher education of diploma program which prepares students for working with certain applied skill to bachelor program. It is relevant with the regulation of research, technology, and higher education minister of Republic Indonesia number 54 Year 2018 on diploma program implementation in opened system of College. Vocation education is required because the bigger nation's competitiveness. Students are directed to develop certain skill and are able to create a work opportunity which is oriented on working skill as the development of knowledge and applied technology.

Vocational education and training experts of VET from Canada, USA, India, China, Japan and Korea, and a number of European countries focus on their national context and how it is appropriate with bigger image [30]. Vocation education is seen as an arrow of young people's unemployment problems [31]. According to the authors, vocation education can improve a nation's quality. It means that the mastery of applied technology for life quality of both work improvement and employment provider can be the main program. Accompanying with full support from the government, this programs becomes the excellence of each country.

\section{The Strengthening of Character Education as the Nation Civilization Control}

Character education should be the control of civilization. It refers to that a good character of a nation will indicates the power of identity. Where is a nation character begun? Certainly, the majority answer is at school. Various efforts have been done to build country's character through education [32] which is started since building the character at school [33], character education principals [34], [35], and integration to build character through curriculum [36]. The importance of character building becomes the main focus of government so that the character education implementation becomes massive and comprehensive in all provinces of Indonesia. The building of work group, school of character education project pilot, and training team of character education at school become the indicator of government's seriousness in building nation character.

\section{Conclusions}

The golden education era will be immediately manifested if the core component of education becomes the main focus. The factors of funding, teachers, and curriculum become the development focusses of this study. 
Opportunities and challenges become the bases of policymaking and education implementation programs. All of them are supported by vocation education as the opportunity of expert and skillful human resource providers who are controlled by good character and morality. This combination will dismiss the stigma and philosophy of Indonesia. Furthermore this research can more focus on discussing the opportunity and challenges of each factor, which significantly affects education.

\section{Acknowledgements}

Many thanks are dedicated to the team of author who has worked hard to organize this article. Each of you could contribute to your job. Thank you for Ahmad Dahlan University and Nanjing Normal University which has fully supported this paper. We also present our gratitude to the editor, reviewer, and journal manager who has provided suggestion until this paper is appropriately published.

\section{REFERENCES}

[1] P. H. Lai and S. SHIRASAKA, "EDUCATION IN MALAYSIA,” New Geogr., vol. 26, no. 2, pp. 26-40, 1978.

[2] X. Shi and P. A. J. Englert, "Reform of teacher education in China," J. Educ. Teach., vol. 34, no. 4, pp. 347-359, Nov. 2008.

[3] Y. Luo and W. Xu, "A Review on The Professional Development of Elementary Education Teachers in China," Int. J. Educ. Learn. Vol 1, No 2 December 2019DO 10.31763/ijele.v1i2.56, Dec. 2019.

[4] J. Jansen, "Educational Change in South Africa 1994-2003 : Case Studies in Large-Scale Education Reform," October, 2003.

[5] R. Strathdee, "Educational reform, inequality and the structure of higher education in New Zealand," J. Educ. Work, vol. 24, no. 1-2, pp. 27-48, Feb. 2011.

[6] L. Parker and K. Prabawa-Sear, "Education in Indonesia," in Environmental Education in Indonesia, Routledge, 2019, pp. 79-94.

[7] S. Kristiansen and Pratikno, "Decentralising education in Indonesia,” Int. J. Educ. Dev., vol. 26, no. 5, pp. 513-531, Sep. 2006.

[8] C. Bjork, "Decentralisation in Education, Institutional Culture and Teacher Autonomy in Indonesia," in Decentralisation and Privatisation in Education, Dordrecht: Springer Netherlands, 2006, pp. 133-150.

[9] Zalik Nuryana, "Curriculum 2013 and The Future of Islamic Education in Indonesia," in International Seminar On Islamic Education 2017, 2017.

[10] B. P. S. N. (BPS), “ndeks Pembangunan Manusia 2018," 2018. [Online]. Available: https://www.bps.go.id/publicati on/2019/08/27/34432798c6ae95c6751bfbba/indeks-pemba ngunan-manusia-2018.html. [Accessed: 14-Nov-2019].

[11] T. Zulfikar, "The Making of Indonesian Education: An overview on Empowering Indonesian Teachers," J. Indones. Soc. Sci. Humanit., 2010.

[12] E. Muslihah, "SCHOOL BASED MANAGEMENT," ALQALAM, vol. 26, no. 3, p. 427, Dec. 2009.

[13] E. James, E. M. King, and A. Suryadi, "Finance, management, and costs of public and private schools in Indonesia," Econ. Educ. Rev., vol. 15, no. 4, pp. 387-398, Oct. 1996.

[14] A. Ahmad and L. Mohd. Tahir, "School Operational Funding to Support School Activities," Int. J. Eval. Res. Educ., vol. 3, no. 1, Mar. 2013.

[15] P. Y. A. Dewi and K. H. Primayana, "Effect of Learning Module with Setting Contextual Teaching and Learning to Increase the Understanding of Concepts," Int. J. Educ. Learn., vol. 1, no. 1, pp. 19-26, Jun. 2019.

[16] Kemdikbud, "Neraca Pendidikan Nasional Tahun 2018," 2018. [Online]. Available: https://npd.kemdikbud.go.id/. [Accessed: 14-Nov-2019].

[17] Kemendikbud, "Praktik Baik Pengelolaan Pendidikan Daerah: Anggaran,” 2018. [Online]. Available: https://npd. kemdikbud.go.id/?appid=praktikbaikv2\&indikator=1. [Acc essed: 14-Nov-2019].

[18] Kemendikbud, "Praktik Baik Pengelolaan Pendidikan Daerah: Akretasi Sekolah," 2018. [Online]. Available: https://npd.kemdikbud.go.id/?appid=praktikbaikv2\&indika tor=4. [Accessed: 14-Nov-2019].

[19] Kemendikbud, "Praktik Baik Pengelolaan Pendidikan Daerah: Guru," 2018. [Online]. Available: https://npd.kem dikbud.go.id/?appid=praktikbaikv2\&indikator=7. [Accesse d: 14-Nov-2019].

[20] E. Garza, Jr, L. Drysdale, D. Gurr, S. Jacobson, and B. Merchant, "Leadership for school success: lessons from effective principals," Int. J. Educ. Manag., vol. 28, no. 7, pp. 798-811, Sep. 2014.

[21] S. Habegger, "The Principal's Role in Successful Schools: Creating a Positive School Culture.," Principal, 2008.

[22] L. Feng and T. R. Sass, "Teacher Quality and Teacher Mobility," Educ. Financ. Policy, vol. 12, no. 3, pp. 396-418, Jul. 2017.

[23] L. Kyriakides, B. P. M. Creemers, and P. Antoniou, "Teacher behaviour and student outcomes: Suggestions for research on teacher training and professional development," Teach. Teach. Educ., vol. 25, no. 1, pp. 12-23, Jan. 2009.

[24] S. M. Brookhart and D. J. Freeman, "Characteristics of Entering Teacher Candidates,” Rev. Educ. Res., 1992.

[25] D. Prideaux, "Curriculum design," BMJ, 2003.

[26] K. Weiler and K. Weiler, "The Child and the Curriculum," in Democracy and Schooling in California, 2011.

[27] Education Scotland, "What is Curriculum for Excellence?," Education Scotland, 2017. .

[28] Z. Nuryana, "Curriculum 2013 and the Future of Islamic 
Education in Indonesia," 2017, pp. 257-270.

[29] D. Y. H. Widodo, "Reconstruction Of Islamic Education Curriculum In The Disruption," IJISH (International J. Islam. Stud. Humanit., vol. 2, no. 1, Aug. 2019.

[30] M. Pilz, The Future of Vocational Education and Training in a Changing World. Wiesbaden: VS Verlag für Sozialwissenschaften, 2012

[31] S. Billett, "The standing of vocational education: sources of its societal esteem and implications for its enactment," J. SVocat. Educ. Train., vol. 66, no. 1, pp. 1-21, Jan. 2014.

[32] N. Burke, S. Crum, M. Genzler, D. Shaub, and J. Sheets, "Building Character Education in Our Schools To Enhance the Learning Environment.," 2001.

[33] R. White and N. Warfa, "Building Schools of Character: A Case-Study Investigation of Character Education's Impact on School Climate, Pupil Behavior, and Curriculum Delivery,” J. Appl. Soc. Psychol., 2011.

[34] T. Lickona, "Eleven Principles of Effective Character Education,” J. Moral Educ., vol. 25, no. 1, pp. 93-100, Mar. 1996.

[35] A. Abdullah, S. Masruri, and K. Bashori, "Islamic Education and Human Construction in The Quran," Int. J. Educ. Learn., vol. 1, no. 1, pp. 27-32, Jun. 2019.

[36] Z. Nuryana and Suyadi, "Character development based on hidden curriculum at the disaster-prone school," J. Educ. Learn., vol. 13, no. 2, pp. 219-225, 2019. 